DOI 10.18551/rjoas.2021-12.17

\title{
ESTIMATING THE TECHNICAL EFFICIENCY OF THE CUCUMBER CROP UNDER DIFFERENT TECHNIQUES: A TRANSLOG STOCHASTIC FRONTIER ANALYSIS
}

\author{
Baban Omar* \\ Al-Turath University College, Iraq \\ Ali Eskander $\mathrm{H}$. \\ University of Baghdad, Iraq \\ Nasif Jasim \\ University of Tikrit, Iraq \\ *E-mail: omar.baban@turath.edu.iq
}

\begin{abstract}
The development of the technical efficiency for the growers will increase the quantity of the crop and lead to higher income and food supply and the improvement of living standards. On the other hand, there is no doubt that excessive irrigation in greenhouse cultivation has a significant negative influence on the crop and causes economic and environmental problems. The research used the method of analysis (SFA) and the application of the transposition function to estimate the levels of technical efficiency of the cucumber crop in Iraq for the production season 2021 under different irrigation systems. A questionnaire was designed for this purpose, and 100 samples were taken for farmers who depend on traditional irrigation and 60 for modern irrigation in Diyala Governorate. The results showed that most of the average efficiency using SFA during the production season 2021 were high. Generally, the results explain that most of the growers in the Diyala governorate were adopting traditional irrigation as a result of poor financial capabilities. On the other hand, the results showed that farmers who adopted modern irrigation have achieved excellent production levels and are in continuous development.
\end{abstract}

\section{KEY WORDS}

Cucumber, technical water efficency, efficiency, stochastic frontier.

There is no doubt that vegetables, including cucumbers, play a crucial role in the human diet (Al-Jubouri, 2021a). They contain many vitamins necessary to supplement people's diet and help protect the body from diseases. Almost all vegetables are low in calories and fat, and many are good sources of fiber (Shettima, Ibrahim, Mohammed and Zongoma, 2016). The agricultural sector has continuously been an essential foundation of the Iraqi agricultural economy, especially in the late twentieth century. As a result, Iraqi agricultural production has increased significantly in recent years (Al-Jubouri, 2021a). Moreover, the success came at a huge financial cost to the farmers (Bai, Salim, and Bloch, 2019). It is worth noting that achieving food security is one of the most controversial matters, especially in developing countries that suffer from increasing population growth, such as Iraq. From this point, modern production technology can be considered crucial to improving technical and economic efficiency (Kenari, Karami, and Ahmadzade, 2017). Then, to develop the level of food security at the global level, there is a necessary need to develop the realization of farmers in agricultural areas in Iraq in order to use resources efficiently (Alem, 2021). The reason for the decline in the productivity of cucumbers on some farms is mostly the inability of farmers to use modern technologies on a large scale (Rahman, Talukder, and Mukta, 2020).

According to Tabe-Ojong and Molua (2017), improving the technical efficiency of growers will lead to an increase in the quantity of yield and increase incomes, food supply and better standards of living. There is no doubt that excessive irrigation in greenhouse 
cultivation has a significant negative impact on the yield and causes economic and environmental problems (Cui, Niu, Du and Zhang, 2020). Cucumbers are widely grown by farmers, whether in greenhouses or solar cultivation in Iraq, as an off-season vegetable due to their high productivity and economic benefits. The option is sensitive to soil water conditions so that the optimal irrigation method may increase production efficiency ( Liu, Yin, Gao, and Hou, 2021). Allocative efficiency refers to the ability to choose optimal inputs levels for given factor prices. In contrast, technical efficiency is defined as the ability to produce a certain level of output with the least amount of inputs under the use of a specific technology (Chandio, Jiang, Gessesse, and Dunya, 2019). Economic researchers explained that there are several basic factors that influence on farmers' efficiency. In order to illustrate, the agent factors are those associated with farm administrator, such as social capital, age and educational level. Meanwhile, farm-related factors are related to farms, such as type of farm, farm location, farm size, agricultural years to analyze technical and economic efficiency (Dadzie and Dasmani, 2010).

\section{LITERATURE REVIEW}

Previous stdies dealt with the Estimating the technical efficiency and the obtained estimates express the mean effects of technologies on performance, apart from the systematic veriances between the technologies. For example, the crisis in Asia and also deadlock in big firmslike Enron in USA, there was a situation of suspicion and disbelief on majority of firms as mentioned by different studies in the litreture review (Alabdullah, 2021; Alabdullah et al, 2014a, 2014b; Alabdullah, 2016a, 2016b, 2016c, 2016d; Falif et al., 2021; Alabdullah, 2018; Ahmed et al., 2018; Alabdullah et al, 2019; Alabdullah et al, 2018; Ahmed, 2014; Alabdullah et al., 2014; Ahmed et al., 2014; ; Ahmed et al., 2021; Alabdullah et al, 2018; Ahmed et al., 2019; Ahmed et al., 2017; Ahmed et al., 2018; Ahmed et al., 2019; Alabdullah, 2016a; Alabdullah et al, 2018; Alabdullah \& Ahmed, 2019; Alabdullah et al, 2016; Ahmed et al., 2016; Alfadhl \& Alabdullah, 2013; Alfadhl \& Alabdullah, 2016; Ahmed et al., 2020; Ahmed et al., 2014; Alabdullah et al, 2020; Alabdullah\& Ahmed, 2020; Alabdullah \& Ahmed, 2018; Alabdullah et al, 2020; Abushammala et al, 2015; Alabdullah et al, 2019; Alabdullah, 2019; Alabdullah, 2017; Ahmed et al., 2020; Ahmed et al., 2020; Ahmed et al., 2020; Alabdullah, 2021a, 2021b; Alabdullah et al, 2021; Nor et al., 2020; Ahmed et al., 2021; Essia, 2014). A series of recent studies referred to the measurement of efficiency by the Stochastic Frontier Analysis (SFA) method. This study will focus on previous studies in the past five years. The majority of studies policy, infrastructure, drainage and fertility (Ogada, Muchai, Mwabu, and Mathenge, 2014). A Stochastic Frontier Analysis (SFA) method has been used extensively in the past have found that the efficiency of some farmers in using the inputs and the irrigation method is weak or not suitable. For example, Esfanjari, Karami, and Ahmadzade (2017) efficiency investigation and measurement of technology gap ratio (TGR) in some greenhouse cucumber growers in Iran. The researchers used the boundary method in analyzing the cross-section data assuming a multilingual functional form. Results of the research showed that the misuse of energy inputs led to a significant decrease in the production efficiency of greenhouse options, as the level of technical efficiency decreased from $98 \%$ to $67 \%$ during $2010-2011$. Moreover, the average percentage of the technology gap in greenhouses has decreased due to lower government subsidies. A recent study by Benedetti, Branca and Zucaro (2019) concluded on estimating the efficiency level using some inputs in agriculture by method (SFA) in Italy. The finding of this paper is that technical efficiency is greatly influenced by the characteristics of individual farms, while organic farms have a lower level of technical efficiency compared to traditional farms. In addition, the fertilization system plays a vital role to increase the level of technical efficiency. Another study done by Kenari et al. (2017) explains the effect of the technology gap ratio in cucumber production as a result of energy subsidies in Iran. They found that reducing energy input subsidies led to a significant decrease in the production efficiency of cucumbers because they are highly dependent on energy.Additionally, the elimination of government grants also reduced the middling technology gap ratio for farmers. The author employed a methodology 
that prescribes the use of Cobb-Douglas to measure resource-use efficiency and volumereturn ratio in off-season cucumber production in Punjab province (Qamar, Ashfaq and Khan, 2017). The result shows that production elasticity was positive for polythene sheets, education, chemicals, fertilizers, days of work and irrigation. On the other hand, there was an inefficient use of seeds and resources with respect to the number of tractors. A study was performed by Rahman et al. (2020), who studied the food security and technical efficiency of cucumber growers in Bangladesh.The study used an (SFA) to appraise profitability and technical efficiency in Bangladesh.They found that growing cucumbers is a profitable agricultural business, but several cucumber growers exhibit ineffective technical problems. The study also revealed that the average technical efficiency rate for the option was approximately $0.73 \%$, representing $26 \%$ inefficiency in the study area. Additionaly, Ghorbani, Radmehr and Habibi (2020) focus on technical efficiency in the agricultural sector in Iran. The study aimed to identify the factors that affect technical efficiency in the agricultural sector. The results of the study revealed that the assumed functional form of the estimation, such as translog function, Cobb-Douglas and SFA - have a clear positive effect on the estimated standard model. Moreover, Ndubueze-Ogaraku and Graves (2020) studied a tested farm's technical efficiency in Nigeria using SFA. The findings included Employment and farm size positively affected technical efficiency.Moreover, the number of years and the age variable in the study were significant at the level of $5 \%$. Subsequently, Bai et al. (2019) investigate environmental and technical efficiencies using the SFA method in some Chinese provinces specializing in apple production. The results indicated that the level of efficiency of the insecticide inputs alone has a usual value of less than $33 \%$. Moreover, it was below the level of environmental efficiency with regards to pests and chemical fertilizers. Finally, the study discovered that labor and material have a complementary relationship while chemical fertilizer and labor have a substitute relationship.Furthermore, Chandio et al. (2019) used the Frontier Random Production Approach to find out the relationship of technical efficiency to farm size and agricultural credit in Pakistan. The results of estimation maximum likelihood estimation (MLE) showed that farm size, credit, labor and fertilizer, and significantly impacted the level of efficiency productivity in Pakistan. Moreover, the average technical proficiency was nearly $97 \%$, which means that only $3 \%$ of rice growers have no technical efficiency.In addition, Thayaparan, Gunathilaka, Pirathepan and Rukshan (2019), the paper presented the agricultural determinants of technical competence in Sri Lanka using the Translog Production Limits Model for data analysis. The estimated Translog Frontier model analysis results revealed that capital, labor costs and raw materials are the necessary determinants of production. Negative and positive signs have been observed, indicating the existence of alternative and complementary effects between the input pair. The extension services, education and land ownership, have been greatly affected by technical competence. Apart from that, Al-Mezeini, Oukil, and Al-Ismaili (2020) discuss and estimate the economic and technical efficiency of greenhouse production in Oman using the data envelope analysis method double bootstrapping method. The results of the research show that $79 \%$ of the greenhouse farmers did not achieve technical competence. Moreover, the consumption of electricity and water was inefficient, ranging from $46 \%$ to $54 \%$, respectively. Other than that, Uuld and Magda (2019) research paper presented the reality of the technical competence of vegetable growers in Mongolia using the SFA model. The results of the study showed that the rate of technical efficiency was about $35 \%$, which means that it was possible to increase the production of household vegetables by more than $60 \%$ at the same input levels if the farmers had technical efficiency.

\section{METHODS OF RESEARCH}

In this paper, we use the SFA approach to estimate technical efficiency. This method considers the non-parameter approach, and it is easy and simple because it does not need the specification of the functional model. Moreover, this approach is required to specify the functional form for production. Meanwhile, Lawson, Bruun, Coelli, Agger, and Lund (2004) states that two stages are used to estimate economic and technical efficiency. The first stage 
evaluated the cucumber farms under the modern irrigation method in the interior of the greenhouses with the inputs for the greenhouses. In the second stage, the efficiency scores are measured in the open cultivation and under the traditional irrigation pattern using the stochastic boundary method with the inputs associated with the production process. The SFA form is suitable for the following reasons: (1) The important feature of this model is that it shows an inefficiency component that is used statistically to measure the degree of technical competence. (2) Since agricultural production generally depends on climatic and natural conditions, the need to define this and separate it from other indicators (Abebe, 2014).

The research was based on primary data collected using 160 questionnaires for cucumber farmers in Diyala Governorate, eastern Iraq. The questionnaire included two irrigation systems. The first sample included 100 farms under the traditional irrigation system. In comparison, the second sample included 60 farms that depended on modern irrigation. The focus was on many demographic, social and economic variables. Still, this research specialized in measuring the technical efficiency of farmers in both systems by using the SFA approach through the translog function. The statistical analysis program (SPSS.V.25) was relied upon to analyze the descriptive statistical measures of the total data.

The strength of any estimated standard model depends on the accuracy of the description of the independent variables that affect the dependent variable. Table (1) shows the dependent variable represented in the quantity of cucumber production measured in kilograms for modern and conventional irrigation, as well as the rest of the independent variables that affect the quantity of cucumber production, as follows:

Table 1 - Description of the variables

\begin{tabular}{|l|l|l|l|}
\hline Variables & Acronym & UNIT & Variable type \\
\hline Output & Y & Kg & dependent \\
\hline seeds & X1 & Gm & independent \\
\hline Organic fertilizers & X2 & $\mathrm{Kg}$ & independent \\
\hline Chemical fertilizers & X3 & Kg & independent \\
\hline Pesticides & X4 & liter & independent \\
\hline Manual labor & X5 & hour / acres & independent \\
\hline Automated work & X6 & hours / acres & independent \\
\hline number of irrigation & X7 & hour / acres & independent \\
\hline
\end{tabular}

Table 2 - Descriptive statistics for traditional irrigation

\begin{tabular}{|c|c|c|c|c|c|c|c|c|c|}
\hline \multicolumn{2}{|l|}{$\mathrm{n} / \mathrm{n}$} & $y$ & $x 1$ & $x 2$ & $x 3$ & $x 4$ & $x 5$ & $x 6$ & $x 7$ \\
\hline \multirow{2}{*}{$\mathrm{N}$} & Valid & 100 & 100 & 100 & 100 & 100 & 100 & 100 & 100 \\
\hline & Missing & 0 & 0 & 0 & 0 & 0 & 0 & 0 & 0 \\
\hline \multicolumn{2}{|l|}{ Mean } & 5814.00 & 349.54 & 842.56 & 384.03 & 4.11 & 489.67 & 17.65 & 28.47 \\
\hline \multicolumn{2}{|c|}{ Std. Error of Mean } & 113.318 & 5.217 & 14.671 & 12.193 & .130 & 12.556 & .458 & .409 \\
\hline \multicolumn{2}{|l|}{ Median } & 5600.00 & 310.00 & 800.00 & 394.50 & 4.00 & 473.35 & 17.30 & 30.00 \\
\hline \multicolumn{2}{|l|}{ Mode } & 5600 & 310 & $800^{a}$ & $260^{a}$ & 4 & 498 & $16^{a}$ & 30 \\
\hline \multicolumn{2}{|c|}{ Std. Deviation } & 1133.17 & 52.17 & 146.71 & 121.92 & 1.304 & 125.56 & 4.57 & 4.08 \\
\hline \multicolumn{2}{|c|}{ Variance } & 1284094.94 & 2722.15 & 21523.70 & 14865.86 & 1.701 & 15766.28 & 20.94 & 16.69 \\
\hline \multicolumn{2}{|l|}{ Skewness } & .252 & .466 & .584 & .437 & .610 & 1.02 & .368 & .746 \\
\hline \multicolumn{2}{|c|}{ Std. Error of Skewness } & .241 & .241 & .241 & .241 & .241 & .241 & .241 & .241 \\
\hline \multicolumn{2}{|l|}{ Range } & 4950 & 215 & 750 & 485 & 6 & 736 & 20 & 20 \\
\hline \multicolumn{2}{|l|}{ Minimum } & 3500 & 250 & 500 & 195 & 2 & 227 & 10 & 20 \\
\hline \multicolumn{2}{|l|}{ Maximum } & 8450 & 465 & 1250 & 680 & 8 & 963 & 30 & 40 \\
\hline \multicolumn{2}{|l|}{ Sum } & 581400 & 34954 & 84256 & 38403 & 411 & 48967 & 1765 & 2874 \\
\hline \multirow{3}{*}{ Percentiles } & 25 & 5200.00 & 310.00 & 750.00 & 275.25 & 3.00 & 398.80 & 14.00 & 25.00 \\
\hline & 50 & 5600.00 & 310.00 & 800.00 & 394.50 & 4.00 & 473.35 & 17.30 & 30.00 \\
\hline & 75 & 6575.00 & 375.00 & 1000.0 & 477.50 & 5.00 & 566.63 & 21.00 & 30.00 \\
\hline
\end{tabular}

\section{RESULTS OF STUDY}

Table (2) explain the results of the descriptive statistical analysis of the inputs and outputs that were used to measure the efficiency of cucumber growers. This study was depended on field data collected for the 2020 production season for traditional irrigation. Through the data of the table, the rate of production per acre, which amounted to (5814) $\mathrm{kg} / \mathrm{acres}$, is a very small amount compared to the production of one acre with the modern 
irrigation system. Hence, it is always encouraged to grow greenhouses, limited to a unit area and with very high productivity. The average quantity of seeds used in the cultivation of one acre is (349.54) g. In contrast, the organic fertilizers rate at the sample level was (842.56) $\mathrm{kg} / \mathrm{acres}$, while the rate of chemical fertilizers was used (384.03) $\mathrm{kg} / \mathrm{acres}$. The dilution of the pesticides, which used a rate of (4.11) liters/acres, the rate of work during the season was (489.67) hours/acres, while the rate of automated work amounted to (17.65) hours. Lastly, the average number of irrigations during the season for the research sample and on the basis of one acre reached (28) waterings per season. The table also shows the highest and lowest quantity of the variables. The highest quantity of production amounted to a level of the sample is $(8450) \mathrm{kg} /$ acres, while the minimum amount of production amounted to (3500) $\mathrm{kg} / \mathrm{acres}$. The highest amount of seeds is (465) g/acres, while the minimum amount of seeds amounted to (250) gm/acres. On the other hand, the highest amount of organic fertilizer amounted to (1250) kg/ acres, while the lowest amount of organic fertilizer was (500) $\mathrm{kg} / \mathrm{acres}$. Moreover, chemical fertilizers were the highest used. At the level of the sample amounted to (680) $\mathrm{kg} / \mathrm{acres}$, the least amount of chemical fertilizer amounted to (195) $\mathrm{kg} /$ acres. This was represented using fertilizers (compound DAB, high-potash, highphosphorous and neutral phosphate fertilizers and Calcium, etc.) as well as pesticides since the cucumber crop is one of the crops that are highly susceptible to fungal infections and insects. Here, it has the highest percentage of use at the sample level, (8) liters/acres. In comparison, some farms were not exposed to injuries and were treated preventively. The lowest percentage of use was (2) liters/acres. Here, the manual work was the highest percentage working hours at the level of the sample, which amounted to (963) hours/acres. This is to cultivate the cucumber crop by the traditional practices' method that requires a lot of agricultural operations and continuous field follow-up. These operations were represented by cultivation, irrigation, hoeing, fertilization (export), harvesting, where these processes require time and labors. The lowest working hours were (227) working hours, as well as automated work, where the highest automatic working hours rate is (30) hours/acres. Furthermore, the minimum labour working hours amounted to (10) hours/acres. This process was limited to (plowing and control). At the same time, the number of irrigations during the season reached the highest number of irrigations (40) at the sample level when it had the lowest number of irrigation during the season, which amounted to (20) irrigation. It is necessary to refer to all the independent variables included in the descriptive analysis statistics measures extracted, as shown in the current table.

Table 3 - Descriptive Statistics (modern irrigation)

\begin{tabular}{|c|c|c|c|c|c|c|c|c|c|}
\hline \multicolumn{2}{|l|}{$\mathrm{n} / \mathrm{n}$} & $y$ & $x 1$ & $x 2$ & $x 3$ & $\mathrm{x} 4$ & $x 5$ & $x 6$ & $x 7$ \\
\hline \multirow[t]{2}{*}{$\mathrm{N}$} & Valid & 60 & 60 & 60 & 60 & 60 & 60 & 60 & 60 \\
\hline & Missing & 0 & 0 & 0 & 0 & 0 & 0 & 0 & 0 \\
\hline \multicolumn{2}{|l|}{ Mean } & 46386.67 & 149.75 & 1119.33 & 402.73 & 15.63 & 1167.47 & 11.28 & 166.38 \\
\hline \multicolumn{2}{|c|}{ Std. Error of Mean } & 969.313 & 4.763 & 56.680 & 16.544 & .585 & 27.693 & .335 & 2.766 \\
\hline \multicolumn{2}{|l|}{ Median } & 48000.00 & 120.00 & 1000.00 & 386.50 & 16.00 & 1194.50 & 11.25 & 165.00 \\
\hline \multicolumn{2}{|l|}{ Mode } & 51200 & 120 & 1000 & 450 & 20 & $884^{\mathrm{a}}$ & 12 & 180 \\
\hline \multicolumn{2}{|c|}{ Std. Deviation } & 7508.266 & 36.897 & 439.043 & 128.147 & 4.53 & 214.512 & 2.595 & 21.424 \\
\hline \multicolumn{2}{|l|}{ Variance } & 56374056.4 & 1361.3 & 192758.8 & 16421.6 & 20.522 & 46015.4 & 6.732 & 458.9 \\
\hline \multicolumn{2}{|l|}{ Skewness } & $-.558-$ & .854 & .870 & 1.212 & -.171 & .214 & .424 & 1.931 \\
\hline \multicolumn{2}{|c|}{ Std. Error of Skewness } & .309 & .309 & .309 & .309 & .309 & .309 & .309 & .309 \\
\hline \multicolumn{2}{|l|}{ Range } & 27600 & 120 & 2100 & 625 & 18 & 985 & 12 & 139 \\
\hline \multicolumn{2}{|l|}{ Minimum } & 30000 & 120 & 400 & 205 & 7 & 730 & 6 & 131 \\
\hline \multicolumn{2}{|l|}{ Maximum } & 57600 & 240 & 2500 & 830 & 25 & 1715 & 18 & 270 \\
\hline \multicolumn{2}{|l|}{ Sum } & 2783200 & 8985 & 67160 & 24164 & 938 & 70048 & 677 & 9983 \\
\hline \multirow[t]{3}{*}{ Percentiles } & 25 & 42000.00 & 120.00 & 750.00 & 310.00 & 12.00 & 999.00 & 9.00 & 150.00 \\
\hline & 50 & 48000.00 & 120.00 & 1000.00 & 386.50 & 16.00 & 1194.50 & 11.25 & 165.00 \\
\hline & 75 & 51200.00 & 180.00 & 1500.00 & 458.00 & 20.00 & 1278.00 & 12.50 & 180.00 \\
\hline
\end{tabular}

Table (3) explains the results of the descriptive statistical analysis of the inputs and outputs used to measure cucumber growers' efficiency under drip irrigation technology. This 
survey was based on field data collected for the 2020 production season for traditional irrigation. The column $(Y)$ represents the quantity of cucumber production measured in kilograms. The average production in the study sample was (46386.67), while the lower rows show the measures associated with descriptive statistics like median and range, mode, standard deviation and variance. Column X1 indicates the number of seeds used in cultivation, where the average amounted to (149.75) gm. Meanwhile, column X2 refers to organic fertilizers. It was measured in kilograms, and its average was (1119.33) kg. Also, column X3 refers to chemical fertilizers, which averaged (402.73). Column X4 explains the result of pesticides with an average of (15.63) liter, while columns X5 and X6 refer to manual labor and automated work, respectively, with an average of (1167.47) and (11.28). Column $\mathrm{X} 7$ shows the number of irrigation hours in the productive season as a whole, where the average hours of irrigation under modern irrigation technology was about 166 hours. It is necessary to refer to all the independent variables included in the analysis. Descriptive statistics measures were extracted for them, as shown in the current table.

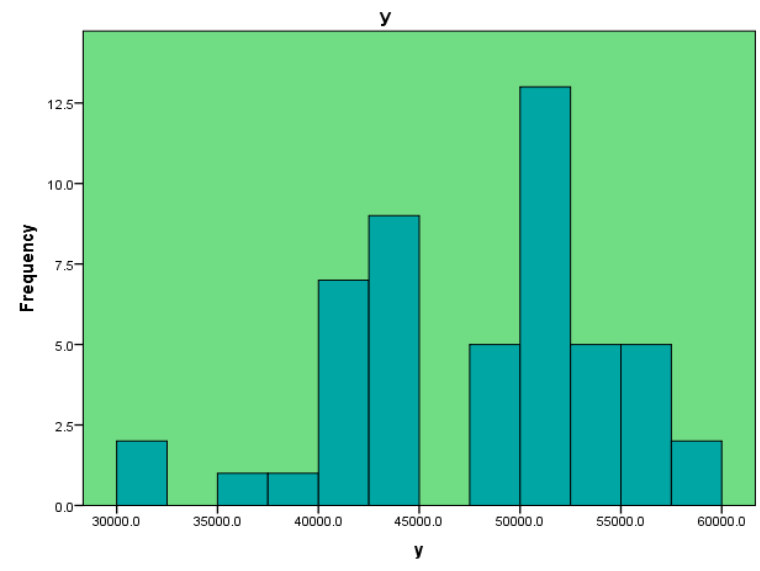

Figure 1 - Histogram in modern irrigation

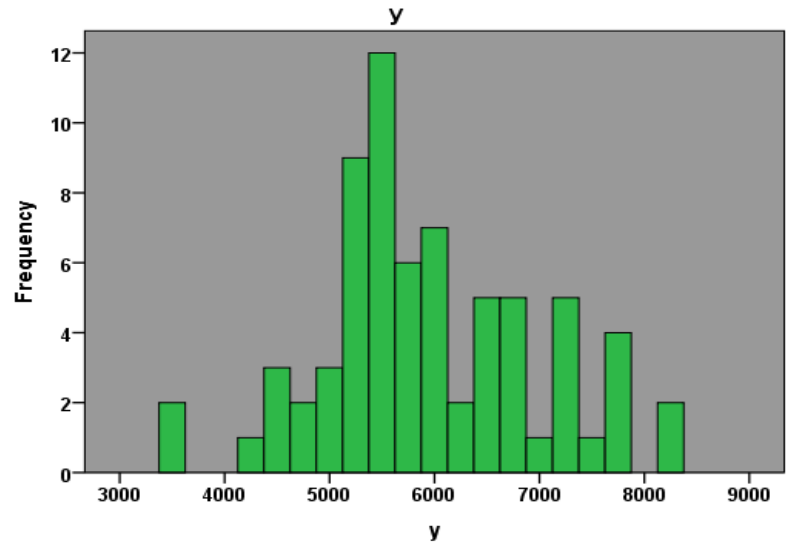

Figure 2 - Histogram in traditional irrigation (mean of outputs)

FRONT 41 is frequently applied in different fields of research, especially in the agricultural sector. This study applied FRONT 41 with the trans-log production for the analysis of technical efficiency. The stochastic frontier approach was used for technical efficiency. The form of the frontier production function used in the study.

$$
\operatorname{Ln} Y=\beta 0+\beta 1 \operatorname{In} X 1+\beta 2 \operatorname{In} X 2+\beta 3 \operatorname{In} X 3+\beta 4 \operatorname{In} X 4+\beta 5 \operatorname{In} X 5+\beta 6 \operatorname{In} X 6+\beta 7 \operatorname{In} X 7+e(U i j-V i j)
$$

The stochastic frontier approach can be written as:

$$
\text { Yit }=f(\text { Xit, } t, \beta) \exp (\text { vit-uit) }
$$

Where: Yit $=$ output; Xit $=$ vector of inputs including $x 1-x 7 ; \beta=$ vector of parameters to be estimated; Vit = random error.

This study uses the Translog production function because it is flexible and provides a second-order approximation of any functional form.

Table (4) explaind the results of technical efficiency estimation of the cucumber crop according to the irrigation system according to the transcendental logarithmic ( $T L$ ) production function by focusing on the basic and using inputs from all the farms of the research sample. It also includes estimates of the technical efficiency and numerical values for the independent variables of the transcendental logarithmic production function obtained. Using the Maximum Likelihood (ML) method, t-test, and Log ML test, the results of the estimation are shown in the table below. The parameters of the production function were estimated using the (OLS) method. After some corrections to their value in the (ML) method, the values are shown in the table below. The parameters will be relied on in the interpretation of the 
relationship between the independent variables in the function and the production quantities of the cucumber crop. Moreover, the parameter value of the variable in the production function represents the productivity elasticity of the resource (the input).

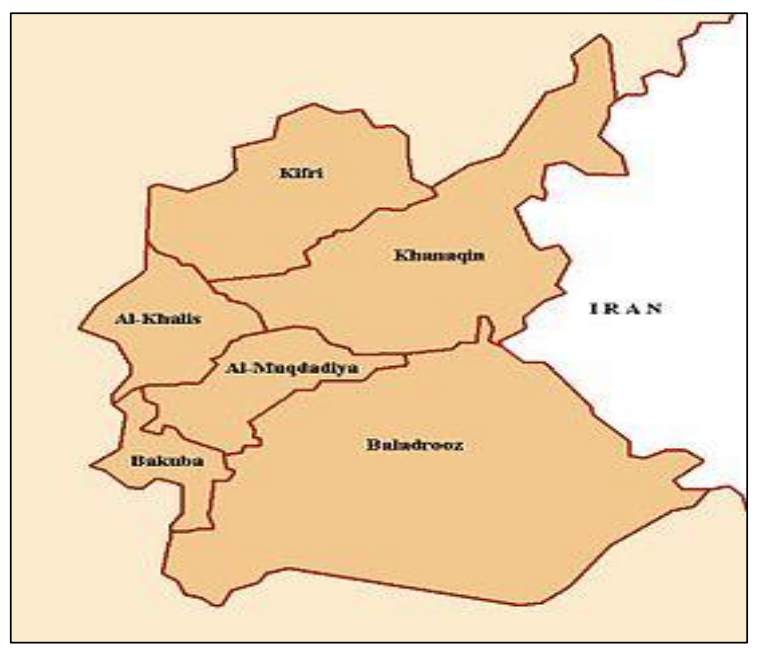

Figure 3 - A map showing the districts of Diyala Governorate in the study area

Table 4 - Estimation of the transcendental logarithmic (TL) production function using the Maximum Likelihood method according to the irrigation system

\begin{tabular}{|c|c|c|c|c|c|c|c|}
\hline $\mathrm{n} / \mathrm{n}$ & \multicolumn{4}{|c|}{ Traditional irrigation } & \multicolumn{3}{|c|}{ Modern irrigation } \\
\hline Variables & Par & Cof. & St. & $t-r$ & Cof. & St. & $t-r$ \\
\hline Constant & $\beta_{0}$ & 4.74 & 1.13 & 4.17 & 9.10 & 1.24 & 7.33 \\
\hline $\mathrm{X} 1$ & $\beta_{1}$ & 0.61 & 0.11 & ${ }^{*} 5.13$ & 0.14 & 0.12 & 1.17 \\
\hline $\mathrm{X} 2$ & $\beta_{2}$ & 0.009 & 0.10 & 0.08 & 0.07 & 0.05 & 1.23 \\
\hline $\mathrm{X} 3$ & $\beta_{3}$ & 0.18 & 0.06 & ${ }^{*} 2.69$ & 0.01 & 0.07 & 0.20 \\
\hline $\mathrm{X} 4$ & $\beta_{4}$ & -0.04 & 0.08 & -0.48 & 0.17 & 0.09 & ${ }^{\star *} 1.88$ \\
\hline$\times 5$ & $\beta_{5}$ & -0.05 & 0.07 & -0.77 & 0.15 & 0.12 & 1.22 \\
\hline$\times 6$ & $\beta_{6}$ & -0.02 & 0.10 & -0.27 & -0.03 & 0.08 & -0.39 \\
\hline $\mathrm{X} 7$ & $\beta_{7}$ & 0.06 & 0.13 & 0.50 & -0.19 & 0.22 & -0.84 \\
\hline Sigma-squared & & 0.03 & 0.01 & 2.37 & 0.05 & 0.01 & 5.27 \\
\hline Gama & & 0.50 & 0.40 & 1.25 & 0.98 & 0.05 & 17.92 \\
\hline LR test & \multicolumn{3}{|c|}{0.269} & \multicolumn{3}{|l|}{6.112} & \\
\hline Log-likelihood function & \multicolumn{3}{|c|}{38.769} & \multicolumn{3}{|l|}{34.824} & \\
\hline
\end{tabular}

Source: Prepared by the researcher based on the data of the questionnaire.

( ${ }^{*}$ shows a level of significance at $1 \%$, while ${ }^{* *}$ indicates a level of significance at $5 \%$ ).

Quantity of seeds. In the traditional irrigation system, the table shows that the value of the parameter amounted to $(0.61)$. It also has a wave sign that shows the direct relationship of the variable with the produced quantities, meaning that an increase in the number of seeds by $1 \%$ will lead to an increase in production by $0.61 \%$, as shown by the value of $(\mathrm{t})$. Therefore, the significance of the variable is about the level of significance of $1 \%$. In the modern irrigation system, the parameter of the variable was $(0.14)$. The positive sign of the parameter indicates the direct relationship of the variable with the dependent variable. An increase in the resource by $1 \%$ leads to an increase in production by $0.14 \%$. In statistical terms, the value of the variable has decreased $(t)$ of (1.17) on the insignificance of the variable.

Organic fertilizers. The value of the variable parameter was positive in agreement with the logic of the economic theory in the traditional irrigation system, which amounted to $(0.009)$. It shows the positive impact on the quantity produced. An increase of this variable by $1 \%$ leads to an increase in production by $0.009 \%$, indicating the use of optimal quantities of 
fertilizers. As for this variable, statistically, the value of (t) indicates the insignificance of the variable, as its value is 0.08 . As for the modern irrigation system, the parameter of the variable is (0.07), with a positive sign indicating the direct relationship of the variable, whereby an increase to the number of organic fertilizers by $1 \%$ leads to an increase in production by a percentage $0.07 \%$. From the statistical point of view, the value of $(\mathrm{t})$ was (1.23), which indicates the insignificance of the variable.

Chemical fertilizers. In the traditional irrigation system, the variable parameter signal was positive and conformed to the logic of the economic theory, which amounted to $(0.18)$. It had a positive impact on production, meaning that an increase in the quantity of the resource by $1 \%$ leads to an increase in the production of the cucumber crop by $0.18 \%$. This indicates that the amount of fertilizer used by farmers is optimal to obtain the desired production rate. The value of $(\mathrm{t})$ indicated the statistical significance of the variable, which amounted to (2.69). As for the modern irrigation system, the variable was parameterized with a positive sign with a value of $(0.01)$. It indicates the positive relationship between the chemical fertilizer variable and the dependent variable. It becomes clear that increasing the number of fertilizers used by $1 \%$ will lead to an increase in production by $0.01 \%$. Therefore, it indicates that there is an increase in the use of fertilizer quantities. The optimized value of (t) indicates the significance of the variable statistically through its value of $(0.20)$.

Pesticides. The parameter of the variable amounted to $(-0.04)$, and the negative sign of the parameter indicates the inverse relationship.Meanwhile, its negative impact on production implies that an increase of $1 \%$ of the pesticides used leads to a decrease in production by $0.04 \%$. This indicates that there is irrational use of pesticides, which negatively affects production. Statistically, the value of $(\mathrm{t})$ was -0.48 , which indicates the insignificance of the variable in the traditional irrigation system. As for the modern irrigation system, the parameter of the variable was positive, reflecting the direct relationship between the variable and the production of the cucumber crop, with a value of $(0.17)$. In contrast, an increase in the number of pesticides by $1 \%$ leads to an increase in production by $0.17 \%$. This is due to the optimal use by the sample farmers in this system for pesticides. The value of ( $t$ ) was (1.88), which indicates the statistical significance of the variable.

Manual work. In the traditional irrigation system, the parameter, through the negative sign, indicates the inverse relationship between manual labor hours and the amount of production, which amounted to $(-0.05)$. This indicates the negative impact that an increase in working hours by $1 \%$ leads to a decrease in production by $0.05 \%$. Statistically, the value of (t) showed the non-significance of the variable through its value of $(-0.77)$. As for the value of the parameter of manual work in the modern irrigation system, it amounted to (0.15). It indicated the direct relationship between the variable and production. This shows that the farmers work optimal working hours. Here, an increase in working hours by $1 \%$ leads to an increase in production by $0.15 \%$. The value of $(t)$ indicates no significance of the variable as its value reached (1.22).

Automated work. The parameter of the automated work variable amounted to $(-0.02)$, where the negative sign reflects the negative relationship between the variable and production. With an increase in automated work hours by $1 \%$, production decreases by $0.02 \%$, which indicates the farmers' use of automated work in a non-optimal and statistically significant way $(\mathrm{t})$ of $(-0.27)$ indicates that the variable is not significant. As for modern irrigation, the value of the variable parameter was $(-0.03)$ with a negative sign, as is the case in the traditional irrigation system. It shows that the sample farmers use automated working hours that exceed the optimal working hours. Accordingly, an increase in automated working hours by $1 \%$ leads to a decrease in production by $0.03 \%$, amounting to the value of $(\mathrm{t}=$ 0.39 ), indicating that the variable is not statistically significant.

Irrigation. In the traditional irrigation system, the irrigation process was represented by the number of irrigations during the season. The parameter value of the variable $(0.06)$ and a positive sign reflects the direct relationship between the variable and the quantities produced from the cucumber crop. It is clear that an increase in the number of irrigations by $1 \%$ leads to an increase in the amount of production by $0.06 \%$. Meanwhile, the $(\mathrm{t})$ value of $(0.50)$ indicated that it was not significant. The value of the parameter in a modern irrigation system 
is $(-0.19)$, with a negative sign that reflects the negative relationship between the variable and production. This indicates that farmers use irrigation hours that exceed the optimal need for irrigation. This is because an increase in irrigation hours by $1 \%$ leads to a decrease in the quantities produced by $0.19 \%$. In addition, the value of $(\mathrm{t})$ of $(-0.84)$ indicates that the variable is not statistically significant. In the traditional irrigation system, the analysis of the technical efficiency of the sample is done according to the MLE method. Using the Frontier program shows us that the highest value of efficiency was 0.96 , which came from the two farms (96-100). These two farms came close to achieving total efficiency as they were able to achieve high productivity through the inputs used. Thus, this farm can produce this amount of production using $96 \%$ of the inputs it uses or less. In comparison, the lowest level of efficiency was $74 \%$, which was at the two farms (64-85). These farms must reach the stage of technical efficiency to produce this amount of production or more using only $74 \%$ of the inputs that they usually use without increasing any amount of economic resources used. The average technical efficiency of the sample farms was (0.90). This value indicates that farmers can increase their production by $10 \%$ without increasing any measure of the economic resources used in the production process. This means that the farmer can produce the same output with fewer resources, approximately $10 \%$ of the resources used. There is a deviation in the actual production at the optimum production by $10 \%$ of the resources used. Resources used for modern irrigation yield the highest technical efficiency reached 0.99 for the farm (59). This farm achieved the highest technical efficiency through the inputs used, while full efficiency can be reached using the same amount of these inputs. The lowest technical efficiency is 0.52 for the farm (14), as this farm needs to reach. It reaches the stage of technical efficiency to produce this amount of production or more using only $52 \%$ of the inputs that are usually used without increasing any amount of the economic resources. Meanwhile, the average technical efficiency of the farm was 0.88 . This value indicates that farmers can increase their production by $12 \%$ without increasing any amount of economic resources used in the production process.

Table 5 - Estimation of technical efficiency according to the irrigation system

\begin{tabular}{|c|c|c|c|c|c|c|c|c|c|c|c|c|c|}
\hline \multicolumn{8}{|c|}{ Traditional irrigation } & \multicolumn{6}{|c|}{ Modern irrigation } \\
\hline farm & TE & farm & TE & farm & TE & farm & TE & farm & TE & farm & TE & Farm & $\mathrm{TE}$ \\
\hline 1 & 0.90 & 26 & 0.94 & 51 & 0.88 & 76 & 0.86 & 1 & 0.89 & 26 & 0.89 & 51 & 0.69 \\
\hline 2 & 0.93 & 27 & 0.87 & 52 & 0.87 & 77 & 0.89 & 2 & 0.94 & 27 & 0.96 & 52 & 0.76 \\
\hline 3 & 0.88 & 28 & 0.90 & 53 & 0.88 & 78 & 0.83 & 3 & 0.92 & 28 & 0.96 & 53 & 0.83 \\
\hline 4 & 0.91 & 29 & 0.88 & 54 & 0.89 & 79 & 0.88 & 4 & 0.98 & 29 & 0.74 & 54 & 0.78 \\
\hline 5 & 0.90 & 30 & 0.89 & 55 & 0.88 & 80 & 0.92 & 5 & 0.96 & 30 & 0.72 & 55 & 0.63 \\
\hline 6 & 0.93 & 31 & 0.91 & 56 & 0.87 & 81 & 0.91 & 6 & 0.80 & 31 & 0.92 & 56 & 0.82 \\
\hline 7 & 0.92 & 32 & 0.92 & 57 & 0.86 & 82 & 0.91 & 7 & 0.82 & 32 & 0.90 & 57 & 0.60 \\
\hline 8 & 0.88 & 33 & 0.88 & 58 & 0.90 & 83 & 0.85 & 8 & 0.75 & 33 & 0.86 & 58 & 0.65 \\
\hline 9 & 0.89 & 34 & 0.89 & 59 & 0.90 & 84 & 0.89 & 9 & 0.83 & 34 & 0.75 & 59 & 0.98 \\
\hline 10 & 0.93 & 35 & 0.91 & 60 & 0.93 & 85 & 0.73 & 10 & 0.95 & 35 & 0.92 & 60 & 0.69 \\
\hline 11 & 0.89 & 36 & 0.92 & 61 & 0.89 & 86 & 0.91 & 11 & 0.70 & 36 & 0.94 & & \\
\hline 12 & 0.93 & 37 & 0.91 & 62 & 0.89 & 87 & 0.90 & 12 & 0.68 & 37 & 0.97 & & \\
\hline 13 & 0.90 & 38 & 0.94 & 63 & 0.75 & 88 & 0.86 & 13 & 0.89 & 38 & 0.93 & & \\
\hline 14 & 0.89 & 39 & 0.85 & 64 & 0.73 & 89 & 0.92 & 14 & 0.52 & 39 & 0.94 & & \\
\hline 15 & 0.94 & 40 & 0.90 & 65 & 0.85 & 90 & 0.90 & 15 & 0.84 & 40 & 0.97 & & \\
\hline 16 & 0.91 & 41 & 0.89 & 66 & 0.84 & 91 & 0.85 & 16 & 0.77 & 41 & 0.81 & & \\
\hline 17 & 0.92 & 42 & 0.94 & 67 & 0.88 & 92 & 0.86 & 17 & 0.59 & 42 & 0.86 & & \\
\hline 18 & 0.90 & 43 & 0.89 & 68 & 0.92 & 93 & 0.92 & 18 & 0.87 & 43 & 0.94 & & \\
\hline 19 & 0.90 & 44 & 0.82 & 69 & 0.92 & 94 & 0.86 & 19 & 0.76 & 44 & 0.83 & & \\
\hline 20 & 0.89 & 45 & 0.84 & 70 & 0.87 & 95 & 0.87 & 20 & 0.67 & 45 & 0.94 & & \\
\hline 21 & 0.86 & 46 & 0.93 & 71 & 0.88 & 96 & 0.82 & 21 & 0.77 & 46 & 0.76 & & \\
\hline 22 & 0.91 & 47 & 0.91 & 72 & 0.89 & 97 & 0.95 & 22 & 0.91 & 47 & 0.92 & & \\
\hline 23 & 0.92 & 48 & 0.94 & 73 & 0.91 & 98 & 0.93 & 23 & 0.75 & 48 & 0.91 & & \\
\hline 24 & 0.90 & 49 & 0.93 & 74 & 0.90 & 99 & 0.94 & 24 & 0.87 & 49 & 0.90 & & \\
\hline 25 & 0.88 & 50 & 0.93 & 75 & 0.92 & 100 & 0.96 & 25 & 0.75 & 50 & 0.94 & & \\
\hline Min & \multicolumn{7}{|l|}{0.74} & Min & \multicolumn{5}{|l|}{0.52} \\
\hline Max & \multicolumn{7}{|l|}{0.96} & Max & \multicolumn{5}{|l|}{0.99} \\
\hline Mean & \multicolumn{7}{|l|}{0.90} & Mean & \multicolumn{5}{|l|}{0.83} \\
\hline
\end{tabular}

Source: Prepared by the researcher based on the data of the questionnaire. 
Table (6) shows the categories and frequency of technical efficiency and their percentage. The categories were in the irrigation system traditional with three categories starting from (70-79). This category included (3) farms at a rate of $3 \%$. As for the second category, it started from (80-89), and this category included (40) farms with a percentage of $40 \%$. As for the third category, it started from 90-99, and this category included (57) farms with a rate of $57 \%$. It indicates that the farmer has high technical efficiency. In modern irrigation, the number of sample categories was (5). The first category started from 50-59 and included one farm with a rate of $1.7 \%$, while the second category started from 60-69 and included (7) farms with a rate of $11.7 \%$. The third category $(0.70-0.79)$ included (14) farms with a rate of $23.3 \%$, while the fourth category from (0.80- 0.89$)$ included (13) farms at a rate of $21.7 \%$. Lastly, the fifth category from (0.90-0.99) had 25 farms with a rate of $41.7 \%$, which is also the highest percentage among the sample categories. This result indicates that most farmers began to achieve high levels of technical efficiency.

Table 6 - Efficiency classes of cucumber crop for modern and traditional irrigation.

\begin{tabular}{|l|l|l|l|l|}
\hline Traditional irrigation & Modern irrigation \\
\hline Categories & frequencies & Percentages & frequencies & Percentages \\
\hline $0.50-0.59$ & 0 & 0 & 1 & 1.7 \\
\hline $0.60-0.69$ & 0 & 0 & 7 & 11.7 \\
\hline $0.70-0.79$ & 3 & 3.0 & 14 & 23.3 \\
\hline $0.80-0.89$ & 40 & 40.0 & 13 & 21.7 \\
\hline $0.90-0.99$ & 57 & 57.0 & 25 & 41.7 \\
\hline Total & 100 & 100.0 & 60 & $100 \%$ \\
\hline
\end{tabular}

Source: Prepared by the researchers based on the outputs of the frontier program and using the SPSS program.

\section{DISCUSSION OF RESULTS}

Cucumbers are widely grown by farmers, whether in greenhouses or solar cultivation in Iraq, as an off-season vegetable due to their high productivity and economic benefits. The option is sensitive to soil water conditions so that the optimal irrigation method may increase production efficiency. The results showed that the technical efficiency averages of cucumber growers using the random stochastic function for the 2021 cropping season were significant and with a perfect average. This finding agrees with the previous study of Rahman et al. (2020). They mentioned that growing cucumbers is a profitable agricultural business, but several cucumber growers exhibit ineffective technical problems. The findings of this study prove that applying (SFA) provides a statistically better result than several measurements of technical efficiency, and this conclusion is consistent with a paper by Dadzieand Dasmani (2010). The comparison between the traditional irrigation system and the modern irrigation system proved that there is a superiority of $(7 \%)$ for the average efficiency in favor of traditional irrigation. This superiority is due to the fact that farmers are still ignorant of the methods of using modern irrigation. This result agrees with the previous study of Al-Mezeini and Al-Ismaili (2020). On the other hand, the negative signs that appeared during the study period for the variables under the traditional and modern irrigation system do not agree with Ghorbani et al. (2020). They reported that the assumed functional form of estimation such as the Translog function, Cobb-Douglas, and Stochastic Frontier Analysis - has a clear positive effect on the estimated standard model.

The findings in this study lead to some implications. The discussion on these implications will be divided into two parts, theoretical and practical.

Theoretical Perspective: First, the results enrich the concepts of technical efficiency and statistical analysis methods for measuring efficiency, such as the trans-functional function. Moreover, this study clarifies the efficiency levels in the traditional and modern irrigation systems and the difference between them to avoid wasting productive resources. After that, this study contributes to both academic society and responsible individuals. Finally, the results may have some essential implications for Iraqi agricultural policy. 
Practical Perspective: The importance of increasing the level of technical competence in the agricultural sector will serve as a guide for workers in this vital sector. Farmers will know the optimum quantities of resources that should be used in the production process. They should not exceed the limits of logical usage and negatively affect production, which will cause the loss of many economic resources and unjustified additional expenses. That is exactly why the agricultural extension agents must exert greater effort in the agricultural fields to achieve optimum efficiency. This effort is not only for the benefit of workers in the agricultural sector but also to reduce waste in the amount of water and preserve the national wealth.

The current study tested the levels of technical efficiency of cucumber farmers under different irrigation techniques for the 2021 production season in Iraq. This was done through a field survey of 100 farms with traditional irrigation and 60 farms with modern irrigation and compared them. This study recommends that subsequent studies must take into account the use of other statistical methods such as the data envelope model or the statistical analysis program (PLS) and the comparison between farms in different regions. Furthermore, this study suggests using the same variables. Still, social variables can be added to show their impact on technical efficiency. Therefore, this study was limited to measuring the technical efficiency of the cucumber crop in Diyala Governorate In Iraq under different irrigation systems for the season 2021 through the method of the trans logical function and analysis of (SFA).

\section{CONCLUSION}

This study presents the results of the analytical process to measure the technical efficiency of cucumber growers by using the translative function model. The research focuses on technical efficiency because it is a fundamental criterion for workers in the agricultural sector. It also focuses on shedding light regarding modern irrigation in order to show its advantages in terms of economic values and water quantity as well as the difference in production. The questionnaire form allowed us to analyze the efficiency and know the optimal levels in order to direct the inputs correctly. The results showed that most of the average efficiency using SFA during the production season 2021 were high. In general, the results proved that most of the growers in the Diyala governorate were adopting traditional irrigation as a result of poor financial capabilities. On the other hand, the results showed that farmers who adopted modern irrigation have achieved excellent levels of production and are in continuous development.

\section{REFERENCES}

1. Abushammala, S. N., Alabdullah, T. T. Y., \& Ahmed, E. R. (2015). Causal Relationship between Market Growth and Economic Growth. Comparison Study. European Journal of Business and Management 7(33).

2. Ahmed, E. R., Alabdullah, T. T. Y., Ardhani, L., \& Putri, E. (2021). The Inventory Control System's Weaknesses Based on the Accounting Postgraduate Students' Perspectives. Journal of Accounting and Business Education, 5(2), 1-8. DOI: http://dx.doi.org/10.26675/jabe.v5i2.19312.

3. Ahmed, E. R., Islam, M. A., Alabdullah, T. T. Y., and bin Amran, A. (2018c). Proposed the pricing model as an alternative Islamic benchmark. Benchmarking: An International Journal 25, 2892-2912. doi: 10.1108/bij-04-2017-0077.

4. Ahmed, E. R., A Amran, Alabdullah, T. T. Y., \& , A Islam (2019). Testing The Legitimacy Index In Light Of Shariah Risks For Sukuk Markets. European Proceedings of Social and Behavioural Sciences 88.

5. Ahmed, E. R. e. A.(2016). Zakat and Accounting Valuation Model. Journal of Reviews on Global Economics, 5(16-24), 24. 
6. Ahmed, E. R., Alabdullah, T. T. Y., Shaharudin, M. S., \& Putri, E. (2020). Further Evidence on the Link between Firm's Control Mechanisms and Firm Financial Performance: Sultanate of Oman. Journal of Governance and Integrity, 4(1), 1-6.

7. Ahmed, E. R., Alabdullah, T. Y., Islam, M. A., \& Asmar, M. (2014) "Sukuk Legitimacy: A New Measurement Based on Content Analysis" 16th Malaysian Finance Association Conference in Sasana Kijang Central Bank of Malaysia, Kuala Lumpur, June 4-6, 2014.

8. Ahmed, E. R., Alabdullah, T. T. Y., Thottoli, M. M., \& Maryanti, E. (2020). Does Corporate Governance Predict Firm Profitability? An Empirical Study in Oman. The International Journal of Accounting and Business Society, 28(1), 127-143.

9. Ahmed, E. R., Aiffin, K. H. B., Alabdullah, T. T. Y., \& Zuqebah, A. (2016). Zakat and Accounting Valuation Model. Journal of Reviews on Global Economics, 5, 16-24.

10. Ahmed, E. R., Islam, M. A., and \&amp; Alabdullah, T. T. Y. (2017). The moderating role of Shariah supervisory board on sukuk pricing benchmark. International Journal of Excellence in Islamic Banking and Finance 6.

11. Ahmed, E. R., Islam, A., Zuqibeh, A., \& Alabdullah, T. T. Y. (2014). Risks management in Islamic financial instruments. Advances in Environmental Biology, 402-406.

12. Ahmed, E. R., Islam, M. A., Alabdullah, T. T. Y., \& Amran, A. B. (2019). A qualitative analysis on the determinants of legitimacy of sukuk. Journal of Islamic Accounting and Business Research, Vol. 10 No. 3, pp. 342-368.

13. Ahmed, E. R., Alabdullah, T. T. Y \& Shaharudin, M. S. (2020). Approaches to Control Mechanisms and Their Implications for Companies' Profitability: a Study in UAE. Journal of accounting Science, Vol. 4, no. 2, pp. 11-20.

14. Ahmed, E. R., Rahim, N. F. A., Alabdullah, T. T. Y., \& Thottoli, M. M. (2019). An examination of social media role in entrepreneurial intention among accounting students: a SEM study. Journal of Modern Accounting and Auditing, 15(12), 577-589.

15. Ahmed, E. R., Alabdullah, T. T. Y., Amran, A., \& Yahya, S. B. (2018). Indebtedness Theory and Shariah Boards: A Theoretical Approach. Global Business and Management Research, 10(1), 127-134.

16. Ahmed, E. R., Islam, M. A., \& Alabdullah, T. T. Y. (2014). Islamic sukuk: Pricing mechanism and rating. Journal of Asian Scientific Research, 4(11), 640.

17. Alabdullah, T. T. Y. (2021). Management accounting insight via a new perspective on the risk management - companies' profitability relationship. International Journal of Intelligent Enterprise 7, in press.

18. Alabdullah, T. T. Y., Ahmed, E. R., and Nor, M. I. (2020). The World Declining Economy And Coronavirus Pandemic: Systems Should Be Continued. Russian Journal of Agricultural and Socio-Economic Sciences 102, 89-96. DOI: 10.18551/rjoas.2020-06.11.

19. Alabdullah, T. T. Y. (2021). Ownership Structure and the Failure or Success of Firm Performance: Evidence from Emerging Market; Cross-sectional Analysis. International Journal of Business and Management Invention, 10(8).

20. Alabdullah, T. T. Y. (2019). Management Accounting and Service Companies' Performance: Research in Emerging Economies, Australasian Accounting, Business and Finance Journal, 13(4), 100-118.doi:10.14453/aabfj.v13i4.8.

21. Alabdullah, T. T. Y. (2017). Compensation committee, company board attributes, and company performance: The moderating effect of leadership position. Paper presented at the 2017 Wei International Academic Conference Proceedings, July 24-27, 2017, Business and Economics.

22. Alabdullah, T. T. Y. (2016a). Are Board Size And Ownership Structure Beneficial In Emerging Markets' Firms? Evidence from Jordan. International Journal of Management \& Information Systems (IJMIS), 20(3), 87-94.

23. Alabdullah, T. T. Y. (2016d). Agency Theory Perspective: A Quantitative Study Of Accounting Performance Measures In Emerging Economies. ICTE Proceedings, NY.

24. Alabdullah, T. T. Y., Ahmed, E. R., \& Nor, M. I. (2018). New Ideas from Management, Finance and Accounting Perspective: The Research for A New Link Between A Company's Outcome and Risk Management. 5th International Conference on New Ideas in Management, Economics and Accounting. 
25. Alabdullah, T. T. Y. (2016c). Corporate Governance from the Perspective of The Past and The Present and The Need to Fill an International Gap. Risk Governance \& Control: Financial Markets \& Institutions, 6(4).

26. Alabdullah, T. T. Y., Yahya, S., \& Ramayah, T. (2014b). Corporate Governance Development: New or Old Concept? European Journal of Business and Management, 6(7), 312-315.

27. Alabdullah, T. T. Y. (2016b). The Performance of Companies and The Board's Characteristics from the New Perspective of Manipulation Avoidance. Corporate Ownership \& Control, 13(4), 279-286.

28. Alabdullah, T. T. Y., Maryanti, E. (2021). Internal Control Mechanisms in Accounting, Management, and Economy: A review of the Literature and Suggestions of New Investigations. International Journal of Business and Management Invention, 10(9).

29. Alabdullah, T. T. Y., Ahmed, E. R. (2021). New Insights to Investigate the Impact of Internal Control Mechanisms on Firm Performance: A Study in Oman. Riset Akuntansi dan Keuangan Indonesia, Vol. 6(2).

30. Alabdullah, T. T. Y., Alfadhl, M. M. A., Yahya, S., \& Rabi, A. M. A. (2014). The Role of Forensic Accounting in Reducing Financial Corruption: A Study in Iraq. International Journal of Business and Management, 9 (1), 26.

31. Alabdullah, T. T. Y., Yahya, S., and Ramayah, T. (2014a). Corporate Governance Mechanisms and Jordanian Companies' Financial Performance. Asian Social Science 10, 247-247. DOI: 10.5539/ass.v10n22p247.

32. Alabdullah, T. T. Y., Ahmed, E. R., (2021). Organization features and profitability: Implications for a sample of Emerging Countries. Journal of Accounting and Business Education, 5(2), 43-52. DOI: http://dx.doi.org/10.26675/jabe.v5i2.16351.

33. Alabdullah, T. T. Y., Ahmed, E. R., Mohammed Almashhadani, M, Yousif S, Almashhadani H, Almashhadani R, Putri, E (2021). How Significantly to Emerging Economies Benefit From Board Attributes and Risk Management in Enhancing Firm Profitability? Journal of Accounting Science 5(2).

34. Alabdullah, T. T. Y., Ahmed, E. R., (2020). A cross-sectional analysis of the influence of corporate governance features on the organizational outcomes: An assessment. International Islamic University Chittagong. 17(2), 6-26.

35. Alabdullah, T. T. Y., Yahya, S., Nor, M. I., \& Majeed, F. Q. (2016). An Investigation of Corporate Governance from a New Perspective: Examining the Financial Performance of Companies and the Impact of Executive Turnover. Corporate Board: Role, Duties \& Composition, 12(1).

36. Alabdullah, T. T. Y., Ahmed, E. R., \& Muneerali, M. (2019). Effect of Board Size and Duality on Corporate Social Responsibility: What has Improved in Corporate Governance in Asia?. Journal of Accounting Science, 3(2), 121-135.

37. Alabdullah, T. T. Y., Ahmed, E. R. (2019). Board Diversity and Disclosure of Corporate Social Responsibility Link: A Study in Malaysia. Journal of Adv Research in Dynamic \& Control System, 11(11).

38. Alabdullah, T. T. Y. (2018). The relationship between ownership structure and firm financial performance. Benchmarking: An International Journal, 25(1), 319-333.

39. Alabdullah, T. T. Y., Laadjal, A., Ries, E., \& Al-Asadi, Y. A. A. (2018). Board Features and Capital Structure in Emerging Markets. Journal of Advanced Management Science, 6 (2).

40. Alabdullah, T. T. Y., Nor, M. I., \& Ahmed, E. R. (2018). The determination of firm performance in emerging nations: Do board size and firm size matter? Management, 5(3), 57-66.

41. Alabdullah, T. T. Y., Ahmed, E. R., \& Nor, M. I. (2019). Do board characteristics provide more enhancement for firm financial performance? A corporate governance perspective. New challenges in corporate governance: Theory and practice (pp. 89-91). https://doi.org/10.22495/ncpr_25.

42. Alabdullah, T. T. Y \& Ahmed, E. R. (2020). Audit Committee Impact on Corporate Profitability in Oman Companies: an Auditing and Management Accounting Perspective. Riset Akuntansi dan Keuangan Indonesia, Vol. 5, no. 2, pp. 121-128. 
43. Alabdullah, T. T. Y. and Ahmed, E. R. (2018). Corporate Governance: To What Extent it is important in the Arab Countries. International Journal of Science and Research 7.

44. Alabdullah, T. T. Y \& Ahmed, E. R. \& Abushammala, S. (2020). Growth of Companies: Empirical Study of the Companies Listed in Developing Economies. Journal of accounting Science, Vol. 4, no. 2, pp. 1-10.

45. Alem, H. (2021). A Metafrontier Analysis on the Performance of Grain-Producing Regions in Norway. Economies, 9(1), 10.

46. Al-Jubouri O., B. A. (2021a). Evaluation of the Efficiency of the Economic Performance of The Arab Company for the Milk in Baghdad Abu Ghraib As A Model for the Extender (2010- 2015), International Journal of Entrepreneurship, 5(22), 1-12.

47. Al-Jubouri O., B. A. (2021b). An Empirical Investigation on Economic Efficiency of Agriculture Banks: Using Deap Method, , International Journal of Entrepreneurship, Volume 25, Special Issue 5, pp 1-12.

48. Al-Mezeini, N. K., Oukil, A., \& Al-Ismaili, A. M. (2020). Investigating the efficiency of greenhouse production in Oman: A two-stage approach based on Data Envelopment Analysis and double bootstrapping. Journal of Cleaner Production, 247, 119160.

49. Alfadhl, M. M. A. F. and Alabdullah, T. T. Y. (2013). Determinants of the Managerial Behavior of Agency Cost and Its Influential Extent on Performance: A Study in Iraq. International Journal of Humanities and Social Science, 3-3.

50. Alfadhl, M. M. A., Alabdullah, T. T. Y. (2016). Agency Cost and Management Behavior: The Role of Performance as a Moderator. International Journal of Science and Research (IJSR), 5(1), 1858-1864.

51. Almashhadani, M. (2021). How Dose Corporate Governance Leverage Organizational Performance: A Survey with Suggestions And Notes For Further Research. Russian Journal of Agricultural and Socio-Economic Sciences 3(111), 3-9.

52. Almashhadani, M. (2020). Testing the effecting elements of R\&D engineer's inventively in design industrialization Sector: A study in Singapore. Journal of Information and Computational Science, 10(5).

53. Almashhadani, M. (2021). A brief Review of Corporate Governance Structure and Corporate Profitability in Developed and Developing economy. Journal of Information and Computational Science,10(11).

54. Al Fakhri, I., Alabdullah, T. T. Y. (2021). The Formation of Rebuts and Reliable Brand Experience Scale in the Malaysian Context. Business Ethics and leadership (BLE).

55. Alsulmani, A.H. et al (2021). Customer Accounting Information and Omani Service Companies' Performance. Int. J. of Finance \& Banking Studies, 10(2), 79-88.

56. Alyaarubi, H. J., Alkindi, D. S., \& Ahmed, E. R. (2021). Internal Auditing Quality and Earnings Management: Evidence from Sultanate of Oman. Journal of Governance and Integrity, 4(2), 115-124.

57. Bai, X., Salim, R., \& Bloch, H. (2019). Environmental Efficiency of Apple Production in China: A Translog Stochastic Frontier Analysis. Agricultural and Resource Economics Review, 48(2), 199-220.

58. Benedetti, I., Branca, G., \& Zucaro, R. (2019). Evaluating input use efficiency in agriculture through a stochastic frontier production: An application on a case study in Apulia (Italy). Journal of Cleaner Production, 236, 117609.

59. Chandio, A. A., Jiang, Y., Gessesse, A. T., \& Dunya, R. (2019). The nexus of agricultural credit, farm size and technical efficiency in Sindh, Pakistan: A stochastic production frontier approach. Journal of the Saudi Society of Agricultural Sciences, 18(3), 348-354.

60. Cui, B. J., Niu, W. Q., Du, Y. D., \& Zhang, Q. (2020). Response of yield and nitrogen use efficiency to aerated irrigation and $\mathrm{N}$ application rate in greenhouse cucumber. Scientia Horticulturae, 265, 109220.

61. Dadzie, S. K., \& Dasmani, I. (2010). Gender difference and farm level efficiency: Metafrontier production function approach.

62. Essia Ries, A. (2014). Islamic Sukuk: Pricing mechanism and rating [Електронний pecypc]/Essia Ries Ahmed, Md. Aminul Islam, Tariq Tawfeeq Yousif Alabdullah. Journal of Asian Scientific Research, (4), 11. 
63. Falih Chichan, H., \& Alabdullah, T. T. Y. (2021). Does Environmental Management Accounting Matter in Promoting Sustainable Development? A study in Iraq. Journal of Accounting Science, 5(2), 114-126.

64. Ghorbani, M., Radmehr, R., \& Habibi, F. (2020). Technical Efficiency in Agriculture. In Resources Use Efficiency in Agriculture (pp. 329-347). Springer, Singapore.

65. Kenari, R. E., Karami, Z., \& Ahmadzade, S. S. (2017). Impact of Energy Subsidies Elimination on Technology Gap Ratio in Cucumber Production. International Journal of Agricultural Management and Development (IJAMAD), 7(1047-2017-1766), 237-244.

66. Liu, H., Yin, C., Gao, Z., \& Hou, L. (2021). Evaluation of cucumber yield, economic benefit and water productivity under different soil matric potentials in solar greenhouses in North China. Agricultural Water Management, 243, 106442.

67. Ndubueze-Ogaraku, M. E., \& Graves, A. (2020). Measuring Farm Technical Efficiency using Stochastic Frontier Production Function Model Approach.

68. Nor, M. I., Masron, T. A., \& Alabdullah, T. T. Y. (2020). Macroeconomic fundamentals and the exchange rate volatility: empirical evidence from Somalia. SAGE Open, 10(1), 2158244019898841.

69. Ogada, M. J., Muchai, D., Mwabu, G., \& Mathenge, M. (2014). Technical efficiency of Kenya's smallholder food crop farmers: do environmental factors matter?. Environment, development and sustainability, 16(5), 1065-1076.

70. Rahman, M. A., Talukder, M. S., \& Mukta, M. A. (2020). Technical efficiency and food security of cucumber farmers in Phulpur Upazila of Bangladesh. Fundamental and Applied Agriculture, 5(2), 202-210.

71. Rahim, N. F. A., Ahmed, E. R., \& Faeeq, M. K. (2018). Internal Control System and Perceived Operational Risk Management in Malaysian Conventional Banking Industry. Global Business \& Management Research, 10(1).

72. Rahim, N. F. A., Ahmed, E. R., Sarkawi, M. N., Jaaffar, A. R., \& Shamsuddin, J. (2019). Operational risk management and customer complaints: the role of product complexity as a moderator. Benchmarking: An International Journal.

73. Shettima, B. G., Ibrahim, A., Mohammed, S. T., \& Zongoma, B. A. (2016). Economic Efficiency of Irrigated Vegetable Production in Borno State Nigeria: A Stochastic Frontier Cost Function Approach. Asian Journal of Agricultural Extension, Economics \& Sociology, 1-14.

74. Singh, K. S. D., Islam, M. A., Ahmed, E. R., \& Amran, A. (2019). An empirical investigation into the major drivers of corporate social responsibility. Opción, 35, 10761090.

75. Thottoli, M. M., Thomas, K. V., \& Ahmed, E. R. (2019a). Examining the impact of information communication technology on auditing professionals: A quantitative study. Journal of Advanced Research in Dynamical and Control Systems, 11(12), 476-488.

76. Thottoli, M. M., Thomas, K. V., \& Ahmed, E. R. (2019b). Qualitative analysis on information communication technology and auditing practices of accounting professionals. Journal of Information and Computational Science, 9(9), 529-537.

77. Thottoli, M. M., Thomas, K. V., \& Ahmed, E. R. (2019c). Adoption of audit software by audit firms: a qualitative study. J. of Information and Comp. Science, 9(9), 768-776.

78. Tabe-Ojong Jr, M. P., \& Molua, E. L. (2017). Technical efficiency of smallholder tomato production in semi-urban farms in Cameroon: A stochastic frontier production approach. J. Mgmt. \& Sustainability, 7, 27.

79. Thayaparan, A., Gunathilaka, G. Y. N., Pirathepan, T., \& Rukshan, A. (2019). Technical Efficiency of Brinjal Farmers in Sri Lanka: Translog Production Frontier Approach.

80. Uuld, A., \& Magda, R. (2019). An Analysis Of Technical Efficiency Of Vegetable's Households In Mongolia. Management (16487974), 35(2).

81. Lawson, L. G., Bruun, J., Coelli, T., Agger, J. F., \& Lund, M. (2004). Relationships of efficiency to reproductive disorders in Danish milk production: a stochastic frontier analysis. Journal of dairy science, $87(1), 212-224$. 